\title{
Physical identification of a chromosomal locus encoding biosynthetic genes for the lipopeptide calcium-dependent antibiotic (CDA) of Streptomyces coelicolor A3(2)
}

\author{
Pei Pei Chong, ${ }^{1}$ Sylvia M. Podmore, ${ }^{1}$ Helen M. Kieser, ${ }^{2}$ \\ Matthias Redenbach, ${ }^{3}$ Kürsad Turgay, ${ }^{4} \dagger$ Mohamed Marahiel, ${ }^{4}$ \\ David A. Hopwood ${ }^{2}$ and Colin P. Smith ${ }^{1}$
}

Author for correspondence: Colin P. Smith. Tel: +44 161200 4183. Fax: +44 1612360409. e-mail : colin.smith@umist.ac.uk

\footnotetext{
1 Department of Biochemistry and Applied Molecular Biology, University of Manchester Institute of Science and Technology (UMIST), PO Box 88, Manchester M60 1QD, UK

2 John Innes Centre, Norwich NR4 7UH, UK

3 Department of Genetics, Genome Research Unit, Kaiserslautern University, 67663 Kaiserslautern, Germany

4 FB Chemie, PhilippsUniversităt, HansMeerwein-Strasse, 35032 Marburg, Germany
}

\section{Putative peptide-synthetase-encoding DNA fragments were isolated from the Streptomyces coelicolor A3(2) chromosome using a PCR-based approach and mapped to a single $\sim 35 \mathrm{~kb}$ segment. In integrative transformation experiments, DNA fragments from this region disrupted production of the calcium-dependent antibiotic (CDA) and had sequences characteristic of non- ribosomal peptide synthetases, thus proving that the cola locus had been cloned.}

Keywords: Streptomyces coelicolor, antibiotic biosynthesis, lipopeptide, gene disruption, peptide synthetase

\section{INTRODUCTION}

Non-ribosomally synthesized peptides constitute one of the most interesting classes of natural products from a biosynthetic point of view (Kleinkauf \& von Döhren, 1996; Lipmann, 1980; Stein \& Vater, 1996). Moreover, they include antibiotics such as the $\beta$-lactams, gramicidin and tyrocidine, immunosuppressants like cyclosporin, and toxins such as enniatin. The synthesis of this class of compounds is directed by large multifunctional enzymes termed peptide synthetases and the corresponding biosynthetic genes have been isolated from a variety of fungi and bacteria, including actinomycetes (e.g. Coque et al., 1991; de Crécy-Lagard et al., 1997; Stachelhaus et al., 1996). Recently, considerable interest has developed in the manipulation of peptide-synthetase-encoding genes from Bacillus spp. and filamentous fungi (Stachelhaus \& Marahiel, 1995; Stachelhaus et al., 1995, 1996; Zuber et al., 1993). The filamentous bacterium

† Present address: Public Health Research Institute, 455 First Avenue, NY 10016, USA.

Abbreviation: CDA, calcium-dependent antibiotic.
Streptomyces coelicolor A3(2) is genetically one of the most studied and amenable micro-organisms and so the study of non-ribosomal peptide synthesis in this organism could add an additional dimension to understanding the genetic control of peptide antibiotic synthesis. A particular feature of this strain is its production of four antibiotics, all of different chemical classes, allowing analysis of the regulation of antibiotic biosynthesis at different levels. These include pathwayspecific regulation, pleiotropic control of more than one antibiotic, and co-regulation of antibiotic production and morphological development (Bibb, 1996; Chater \& Bibb, 1997; Hopwood et al., 1995).

The structure of three of the four $S$. coelicolor antibiotics has been known for some time, but that of the fourth, the calcium-dependent antibiotic (CDA; Hopwood \& Wright, 1983; Lakey et al., 1983; Lakey \& Ptak, 1988), was not. However, on the basis of some similarities between the action of CDA and of amphomycin and LY146032 on biological membranes (Lakey et al., 1983, 1988), it was surmised that CDA might be a lipopeptide, containing a non-ribosomally derived peptide moiety (Hopwood et al., 1995). An attempt to clone the 
biosynthetic genes for CDA was therefore based on this premise. This succeeded, as described here. Meanwhile, chemical characterization of CDA has indeed shown it to be a lipopeptide antibiotic consisting of 11 amino acid residues, with a 6-carbon hydroxylated fatty acid at the N-terminus (Kempter et al., 1997).

\section{METHODS}

Bacterial strains, plasmids and microbiological procedures. The $S$. coelicolor $c d a^{+}$strain 2377 has been described by Hopwood \& Wright (1983) and was handled by procedures described by Hopwood et al. (1985). For S. coelicolor MT1109, a prototrophic strain, see Podmore (1995). The cosmid clones were from the library described by Redenbach et al. (1996). The Escherichia coli non-methylating host was ET12567 (MacNeil et al., 1992). Plasmid vectors pMT3008 and pMT3009 have been described by Paget (1994) and pBluescript II SK(+) was from Stratagene. For tests of CDA production (e.g. Fig. 5), two Oxoid nutrient agar (ONA) plates supplemented with histidine and uracil were inoculated with spores from a single colony of each culture. After incubation for $48-60 \mathrm{~h}$ at $30^{\circ} \mathrm{C}$, the two plates were overlaid with soft ONA containing a strain of Bacillus mycoides as indicator (Hopwood \& Wright, 1983); $\mathrm{Ca}\left(\mathrm{NO}_{3}\right)_{2}$ was added to one plate to a final concentration of $12 \mathrm{mM}$ (Podmore, 1995). Plates were examined for calcium-dependent antibiosis after $16 \mathrm{~h}$ further incubation at $30^{\circ} \mathrm{C}$.

DNA manipulations. General procedures were as described by Hopwood et al. (1985) for Streptomyces and Sambrook et al. (1989) for E. coli. The PCR conditions were 35 cycles with Taq polymerase in the presence of $5 \%$ DMSO. Each cycle was $1 \mathrm{~min}$ at $94^{\circ} \mathrm{C}, 1 \mathrm{~min}$ at $55^{\circ} \mathrm{C}$ and $1 \mathrm{~min}$ at $72{ }^{\circ} \mathrm{C}$.

\section{RESULTS}

\section{Use of synthetic oligonucleotide probes to isolate PCR products carrying putative peptide-synthetase- encoding genes using S. coelicolor DNA as template}

As a strategy to clone a putative peptide synthetase gene(s) from S. coelicolor, two degenerate oligonucleotides were designed to encode the conserved motifs 'Core I' (KAGGA) and 'Core II' (SGTTG), revealed by aligning the amino acid sequences of a series of peptide synthetases (e.g. Borchert et al., 1992; Turgay \& Marahiel, 1994) using Streptomyces codon usage (Wright \& Bibb, 1992) and incorporating an EcoRI site at each $5^{\prime}$ end (Fig. 1). These oligonucleotides were used as PCR primers, with $S$. coelicolor chromosomal DNA partially digested with HindIII as template. This yielded an apparently doublet amplified band of approximately the expected length. DNA from this band was cloned into the EcoRI site of pBluescript II $S K(+)$. The nucleotide sequences of five of the clones were determined. All had a G $+C$ content of $\sim 70 \%$ (characteristic of Streptomyces DNA). The clones fell into three non-overlapping classes, represented by fragments A, B and C. Clones A and B represented the smaller PCRamplified band (239 and $244 \mathrm{bp}$, respectively) and encoded sequences that were $82 \%$ similar to each other, while clone $\mathrm{C}$ was longer ( $306 \mathrm{bp}$ ) and its product was only $60 \%$ similar to that of the other two clones. The sequences of all three clones revealed partial open reading frames for proteins highly similar to known peptide synthetases (data not shown).

\section{Use of PCR products to clone putative CDA biosynthetic genes from $S$. coelicolor}

The $c d a$ locus had been mapped genetically (Hopwood $\&$ Wright, 1983) to a region of the $S$. coelicolor linkage map later deduced to correspond to the AseI-E fragment of the physical map (Kieser et al., 1992). Significantly, all three cloned PCR products (A, B and C) hybridized uniquely to this fragment. When the $B$ fragment was used as a probe against an unordered library of cosmid clones corresponding to the AseI-E fragment (Redenbach et al., 1996), it hybridized to six cosmids, designated 2B7, 2E5, 3D10, 4C5, 6D5 and 6E4. The six cosmids and S. coelicolor chromosomal DNA were subjected to Southern analysis using each of the three PCR products as probes (Fig. 2). Probes A and B yielded identical hybridization patterns, whereas probe $C$ hybridized to different fragments; cosmids 2B7, 2E5 and 4C5 contained sequences that hybridized to all three probes, whereas DNA from the other three cosmids (3D10, 6D5 and 6E4) hybridized only to the A/B probes. It is notable that all the chromosomal sequences that hybridized with the three PCR products are represented by the six cosmids (Fig. 2). Restriction mapping of these cosmids showed them to overlap extensively, together spanning $88 \mathrm{~kb}$, and demonstrated that all the sequences that hybridized to one or more of the PCR products are contained within one contiguous segment of $\sim 35 \mathrm{~kb}$ (Fig. 3). Use of a segment of the overlapping DNA as a probe against the ordered cosmid encyclopaedia covering the entire $S$. coelicolor A3(2) chromosome (Redenbach et al., 1996) located the DNA on the overlap between cosmids E8 and E63.

\section{Gene disruption demonstrates that the cloned peptide-synthetase-encoding sequences are required for CDA biosynthesis}

The above Southern analysis identified five small SalI fragments of $1.5-4.3 \mathrm{~kb}$ that hybridized to either the A/B peptide synthetase probes (Sall fragments AB2.1, $\mathrm{AB} 2.5$ and $\mathrm{AB} 4.3$ ) or the $\mathrm{C}$ probe (Sall fragments $\mathrm{C} 1.5$ and $\mathrm{C} 2.5$ ) (Fig. 2); their approximate map locations are shown in Fig. 3. The observed hybridization of each PCR product to more than one SalI fragment is considered to be attributable to heterologous hybridization of the clones to different peptide synthetase modules; different amino acid activating modules within peptide synthetases share differing degrees of sequence similarity (e.g. Coque et al., 1991; Stachelhaus \& Marahiel, 1995). The simplest interpretation of the Southern analysis is that the three PCR products (A-C) collectively hybridize to five different peptide synthetase modules. The above SalI fragments were chosen for targeted gene disruption experiments to investigate their involvement in CDA biosynthesis. They were each cloned into either pMT3008 or pMT3009, E. coli vectors based on pBR322 that contain, respectively, a hygromycin-resistance gene (byg) and a thiostrepton- 
Primer 1 (Core I: 'KAGGA' motif)

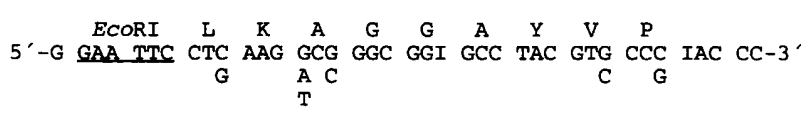

Primer 2 (Core II: 'SGTTG' motif)

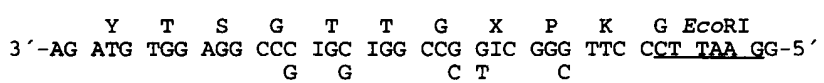

Fig. 1. Degenerate oligonucleotide primers used for PCR amplification of putative peptide-synthetase-encoding DNA fragments from the $S$. coelicolor chromosome. The consensus amino acid sequences of the Core I and Core II motifs are indicated above the respective DNA sequences.

resistance gene $(t s r)$ for selection in Streptomyces. The resulting recombinants were passaged through the nonmethylating E. coli strain ET12567 and used to transform $S$. coelicolor 2377 . This is the $c d a^{+}$strain used by Hopwood \& Wright (1983) as a parent for the $c d a$ mutants used in genetic mapping of the $c d a$ locus. Selection for hygromycin- or thiostrepton-resistant transformants yielded recombinants in which a single crossover resulted in integration of the plasmid into the region of the chromosome homologous with the cloned Sall fragment. The expected genomic structure of two independent integrants derived from each disrupting plasmid was confirmed by Southern hybridization and at least four independent transformants for each construct were tested for CDA production. Plasmid integration via four of the fragments $(\mathrm{AB} 2.1, \mathrm{AB} 2.5, \mathrm{AB} 4.3$ and $\mathrm{C} 1.5$ ) led to almost complete inhibition of CDA production by the respective transformants, whereas integration via $\mathrm{C} 2.5$ caused a lesser reduction in CDA production as judged by plate bioassays (data not shown).

These results provided presumptive evidence of the direct involvement of the cloned DNA in CDA biosynthesis. The slight 'leakiness' of the $\mathrm{Cda}^{-}$phenotype of these single-crossover disruptants was attributed to excision of the disrupting plasmid by a reversal of the integration event in a small proportion of the chromosomes in the tested mycelial patches, an event that could not be selected against because antibiotic selection had to be omitted from the test plates so as not to inhibit the indicator bacterium B. mycoides. A gene replacement was therefore made by targeted double crossing-over in an attempt to generate a stable $c d a$-null mutant. To do so, two of the SalI fragments (AB2.1 and AB2.5 in Fig. 3) were cloned on either side of the $t s r$ gene, in their natural chromosomal orientation, in the pMT3008 vector to yield pMT3350 (Fig. 4). Strain 2377 was transformed with this plasmid, with selection for hygromycin resistance, to yield single-crossover integrants. Four of these were shown by Southern hybridization to have arisen by homologous recombination via either the AB2.1 or the AB2.5 fragment (two in each). As before, the recombinants had a leaky $\mathrm{Cda}^{-}$phenotype.
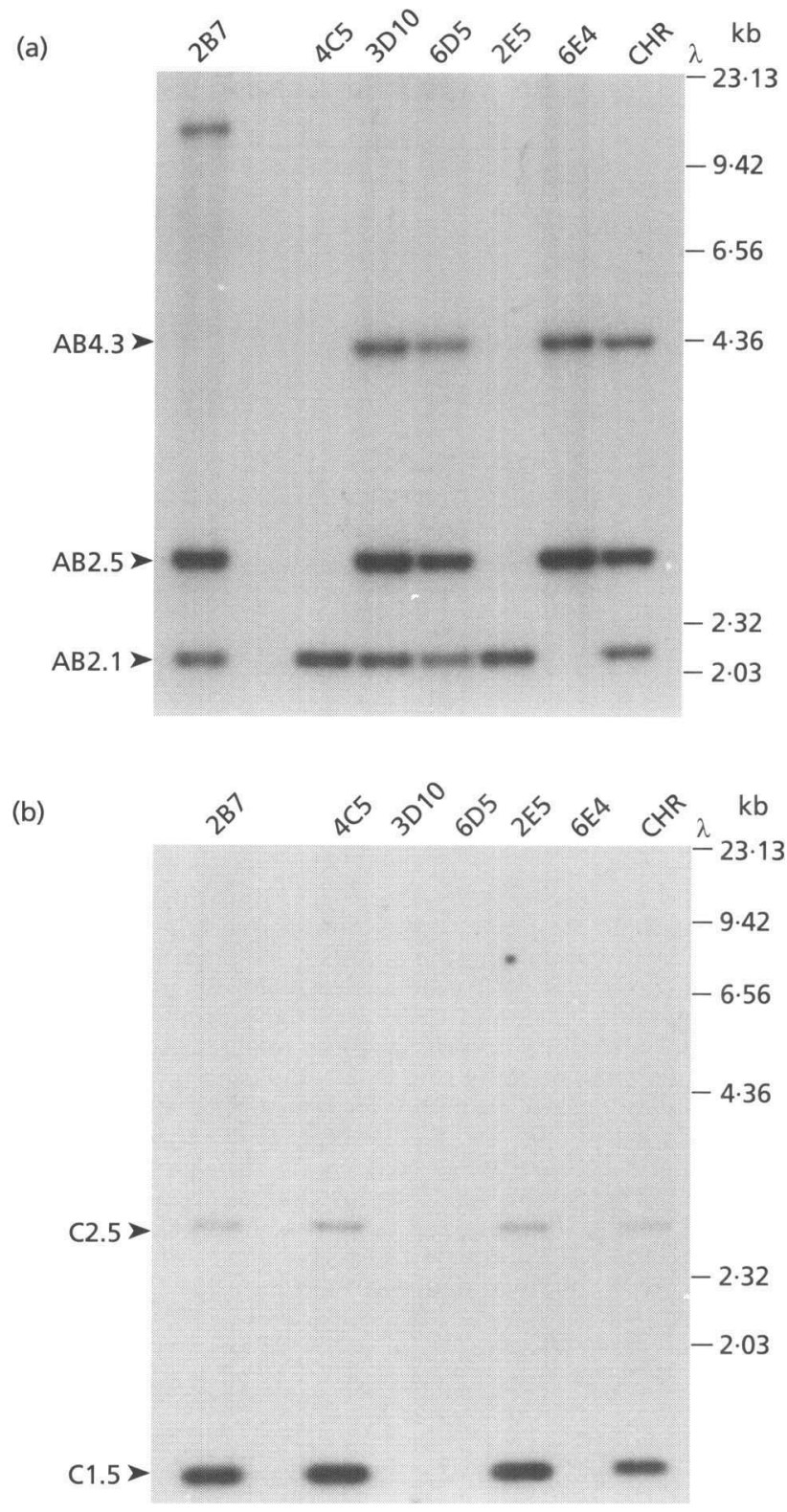

Fig. 2. Southern analysis of S. coelicolor MT1109 chromosomal DNA (CHR) and the six putative peptide-synthetase-encoding cosmids (2B7-6E4). All DNA samples were digested with Sall. HindIII-digested $\lambda$ DNA was used as a size marker (indicated on the right of each autoradiograph). (a) Hybridization with radiolabelled PCR fragment $B$ (an identical hybridization pattern was obtained using PCR fragment A). (b) Hybridization with radiolabelled $P C R$ fragment $C$. The five hybridizing Sall fragments used in gene disruption experiments are indicated to the left (coded as in Fig. 3).

Two of the integrants generated by crossing-over in fragment AB2.5 were grown non-selectively and $\mathrm{Hyg}^{\mathrm{S}}$ Thio $^{R}$ segregants were recovered. Southern analysis of five of them showed that the expected second crossover, in fragment $A B 2.1$, had occurred, resulting in the replacement of the $8.2 \mathrm{~kb}$ segment of chromosomal DNA lying between the two SalI fragments by the $t s r$ 


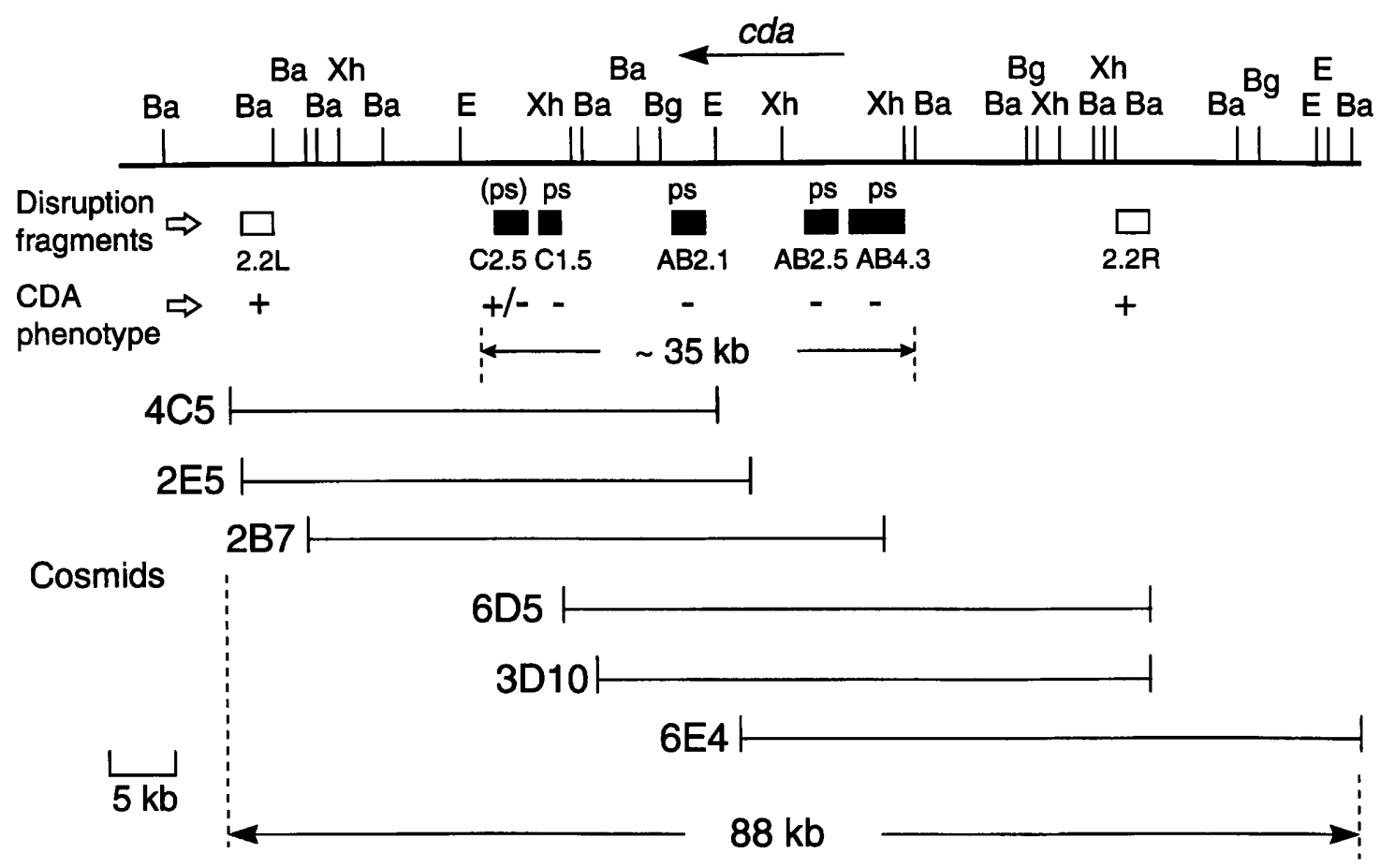

Fig. 3. Physical map of the putative peptide-synthetase-encoding cda locus. The extent of each cosmid insert is indicated below the map, and the approximate physical locations of the Sall fragments (indicated by black boxes) that hybridize to the respective PCR products (see Fig. 2) are indicated. The relative positions of the two fragment-C-hybridizing Sall fragments, C1.5 and C2.5, within the EcoRI-Xhol segment has not been established. The restriction map was deduced from a combination of Southern analysis using the PCR products, conventional restriction mapping of the cosmids and directional mapping of partially digested cosmids using T3 and T7 oligonucleotide probes (see Evans et al., 1989); in the latter approach, cosmids were digested to completion with Asel before partial digestion with the respective enzymes. All sites are shown for BamHI (Ba), Bg/ll (Bg), ECoRI (E) and Xhol (Xh). The seven fragments used in gene disruption experiments are indicated, as is the CDA production phenotype of the respective disruptants. The DNA segment flanked by Sall fragments AB2.1 and AB2.5 has been deleted in strain MT1160 (see Fig. 4). 'ps' indicates that the DNA fragment contains an (incomplete) open reading frame for a protein homologous to known peptide synthetases; only one end of fragment C2.5 contained such an open reading frame. The direction of transcription of one cda segment is indicated by an arrow, and was deduced from the DNA sequences of the ends of fragments AB2.1 and AB2.5 relative to the physical map.

marker (Fig. 4). Plate tests (e.g. Fig. 5) showed that all five strains produced no detectable CDA.

To gain some insight into the length of DNA involved in CDA biosynthesis, single-crossover disruptions were made with two fragments from near the ends of the $\sim 88 \mathrm{~kb}$ chromosomal region encompassed by the six overlapping cosmids; these were two $2.2 \mathrm{~kb}$ EcoRIBamHI fragments from the left extremity of cosmid 2E5 and the right extremity of cosmid 3D10 (2.2L and 2.2R, respectively; Fig. 3 ). In both cases the site of integration was confirmed by Southern analysis; CDA production was not affected in either class of integrant as judged from plate bioassays (data not shown).

\section{Sequencing of cda DNA reveals similarities to known peptide synthetases}

Short lengths of sequence were obtained from each end of the seven fragments that were used in the gene disruption experiments. The derived amino acid sequences from both ends of the four fragments that disrupted CDA production aligned well with those of peptide synthetases from a variety of organisms, while the sequence from only one end of fragment C2.5 did so. Conversely, the deduced sequences of the flanking $2.2 \mathrm{~L}$ and $2.2 \mathrm{R}$ fragments showed no similarities to peptide synthetases.

\section{DISCUSSION}

The results described here provide clear evidence for the cloning of one or more structural genes encoding a peptide synthetase for the lipopeptide antibiotic CDA. We have isolated and physically mapped a DNA segment corresponding to $\sim 1 \%$ of the $S$. coelicolor chromosome, and all putative peptide-synthetase-encoding DNA fragments identified in this study were contained in a $\sim 35 \mathrm{~kb}$ region within this segment. It should be noted that, because of the inherent variability in the extended Core I and Core II motifs, the PCR primers 

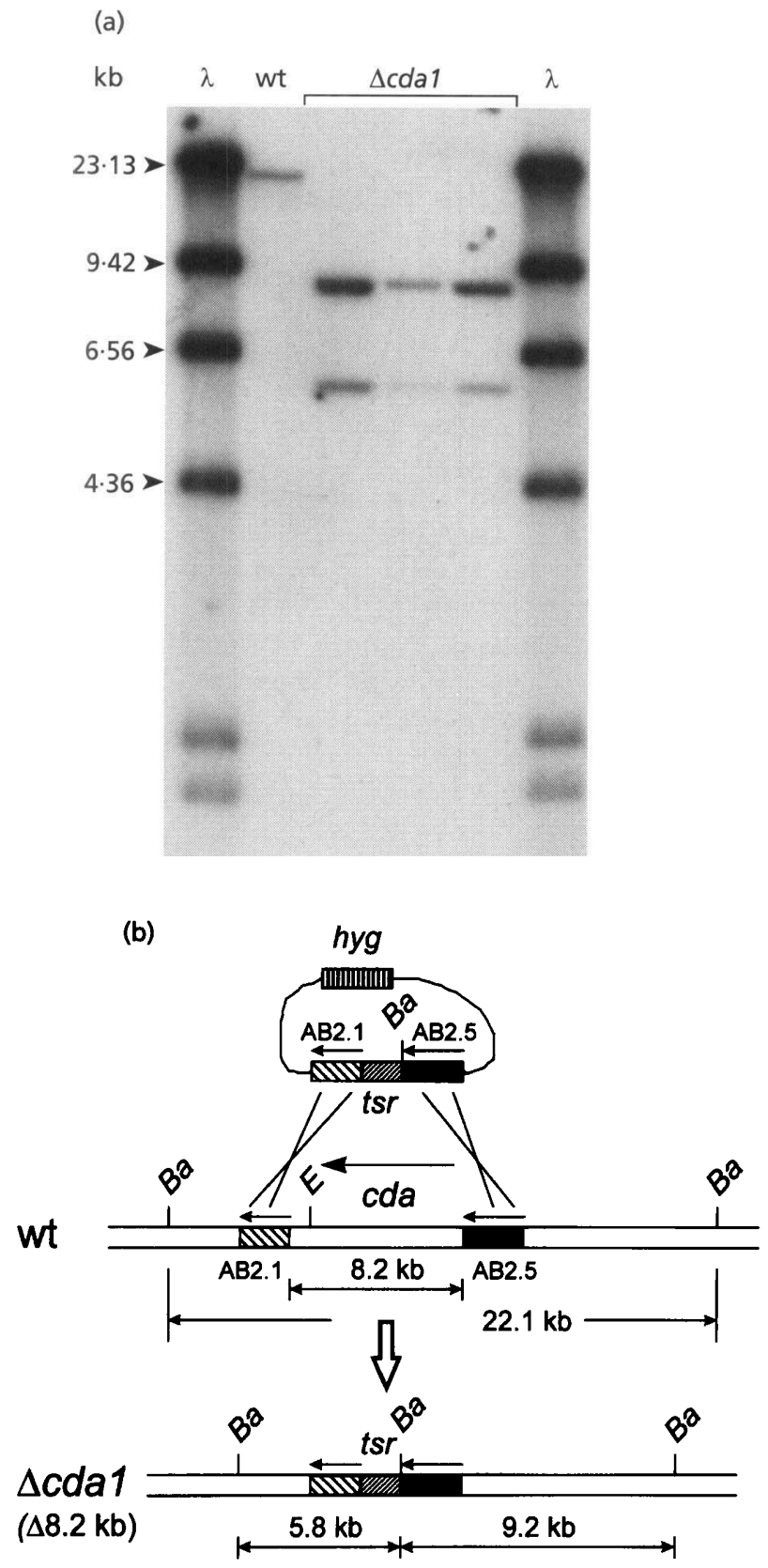

Fig. 4. Construction of a stable cda null mutant, MT1160, containing the $\Delta c d a 1$ mutation. (a) Southern analysis of chromosomal DNA from three independent $\Delta \mathrm{cda} 1$ clones. Sall fragment AB2.5 was used as the radiolabelled probe. $\lambda$, HindIIIdigested $\lambda$ DNA; wt, $S$. coelicolor 2377 chromosomal DNA. All chromosomal DNA was digested with BamHI. (b) Schematic representation of the double-crossover gene replacement. The $8.2 \mathrm{~kb}$ DNA segment between the AB2.1 and AB2.5 Sall fragments (Fig. 3) was replaced with the tsr gene and the resulting DNA segment was cloned into the delivery plasmid pMT3008 to produce pMT3350.

used in this study would not be expected to amplify the 'KAGGA/SGTTG' encoding sequences from all peptide synthetase domains. It cannot therefore be ruled out that there may be other peptide-synthetase-encoding loci elsewhere in the $S$. coelicolor chromosome.

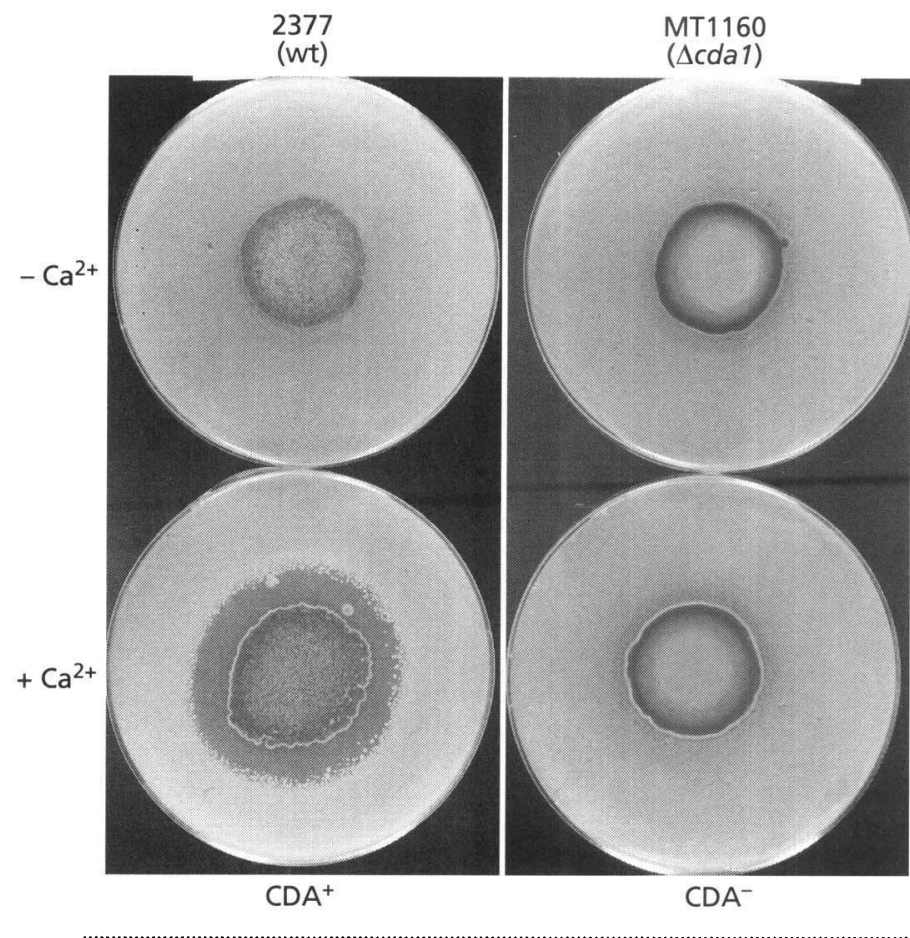

Fig. 5. CDA plate bioassays of wild-type S. coelicolor 2377 and the $\Delta c d a 1$ null mutant, MT1160. Calcium-dependent antibiosis is only observed with strain 2377 .

Assuming that the segment of the synthetase required to activate and incorporate each amino acid into the peptide would be encoded by about $3.5 \mathrm{~kb}$ DNA (e.g. Turgay et al., 1992), $\sim 39 \mathrm{~kb}$ would be required to synthesize the 11-residue oligopeptide moiety of CDA. Other genes must be involved in the synthesis of some of the unusual amino acid residues themselves, as well as for some other post-assembly modifications of the structure. In addition, synthesis and attachment of the fatty acid at the $\mathrm{N}$-terminus of CDA presumably requires some dedicated genes. If, as expected from precedent, all the biosynthetic genes for synthesis of the antibiotic are clustered together on the chromosome, it is likely that all genes required for CDA production are contained within the $88 \mathrm{~kb}$ DNA segment reported here. The two flanking fragments (2.2L and 2.2R; Fig. 3) used in single-integration disruptions did not influence CDA production, indicating that they were not internal to transcription units required for CDA synthesis. The extent of the $c d a$ cluster and its detailed organization are currently under investigation.

A particularly relevant question concerns genetic control of the biosynthesis of the fatty acid moiety of CDA and whether this involves a kind of developmental cross-talk between the vegetative fatty acid synthase and the CDA peptide synthetase (Hopwood, 1997). Elucidation of this question will throw further light on the interrelationships between fatty acid biosynthesis and that of at least two polyketide metabolites of $S$. coelicolor, the antibiotic actinorhodin and the spore pigment (Revill et al., 
1995, 1996; Yu \& Hopwood, 1995). This is a specific example of the special interest in studying the genetics of several interrelated primary and secondary metabolites in one and the same genetically amenable microorganism (Hopwood et al., 1995).

\section{ACKNOWLEDGEMENTS}

We gratefully acknowledge Richard Losick's contribution in suggesting the PCR-based approach to isolating peptidesynthetase-encoding genes from S. coelicolor and thank Fiona Flett for helpful discussions. P.P.C. is the recipient of a UMIST Graduate Research Scholarship and an Overseas Research Student Award (from the CVCP, UK). S. M.P. was supported by a $\mathrm{PhD}$ studentship from the former Chemicals and Pharmaceuticals Directorate of the Biotechnology and Biological Sciences Research Council, UK (BBSRC). This work benefited from the use of the Seqnet facility (Daresbury, UK). Work at the John Innes Centre was supported by grantsin-aid from the BBSRC and the John Innes Foundation. Work in Marburg was supported by the Deutsche Forschungsgemeinschaft and the Fonds der Chemischen Industrie.

\section{REFERENCES}

Bibb, M. J. (1996). The regulation of antibiotic production in Streptomyces coelicolor A3(2). Microbiology 142, 1335-1344.

Borchert, S., Patil, S. S. \& Marahiel, M. A. (1992). Identification of putative multifunctional peptide synthetase genes using highly conserved oligonucleotide sequences derived from known synthetases. FEMS Microbiol Lett 92, 175-180.

Chater, K. F. \& Bibb, M. J. (1997). Regulation of bacterial antibiotic production. In Products of Secondary Metabolism (Biotechnology, vol. 7), pp. 57-105. Edited by H.-J. Rehm \& G. Reed. Weinheim: VCH.

Coque, J. J. R., Martín, J. F., Calzada, J. G. \& Liras, P. (1991). The cephamycin biosynthetic genes $p c b A B$, encoding a large multidomain peptide synthetase, and $p c b C$ of Nocardia lactamdurans are clustered together in an organisation different from the same genes in Acremonium chrysogenum and Penicillium chrysogenum. Mol Microbiol 5, 1125-1133.

de Crécy-Lagard, V., Blanc, V., Gil, P., Naudin, L., Lorenzon, S., Famechon, A., Bamas-Jacques, N., Crouzet, J. \& Thibaut, D. (1997). Pristinamycin I biosynthesis in Streptomyces pristinaespiralis: molecular characterization of the first two structural peptide synthetase genes. J Bacteriol 179, 705-713.

Evans, G. A., Lewis, K. \& Rothenberg, B. E. (1989). High efficiency vectors for cosmid microcloning and genomic analysis. Gene 79, 9-20.

Hopwood, D. A. (1997). Genetic contributions to understanding polyketide synthases. Chem Rev 97, 2465-2497.

Hopwood, D. A. \& Wright, H.M. (1983). CDA is a new chromosomally-determined antibiotic from Streptomyces coelicolor A3(2). J Gen Microbiol 129, 3575-3579.

Hopwood, D. A., Bibb, M. J., Chater, K. F., Kieser, T., Bruton, C. J., Kieser, H. M., Lydiate, D. J., Smith, C. P., Ward, J. M. \& Schrempf, H. (1985). Genetic Manipulation of Streptomyces: a Laboratory Manual. Norwich: John Innes Foundation.

Hopwood, D. A., Chater, K. F. \& Bibb, M. J. (1995). Genetics of antibiotic production in Streptomyces coelicolor A3〈2), a model streptomycete. In Genetics and Biochemistry of Antibiotic Production, pp. 65-102. Edited by L. C. Vining \& C. Stuttard. Newton, MA: Butterworth-Heinemann.
Kempter, C., Kaiser, D., Haag, S. \& 8 other authors (1997). CDA: calcium-dependent peptide antibiotic from Streptomyces coelicolor A3 (2) containing unusual residues. Angew Chem Int Ed Engl 36, 498-501.

Kieser, H. M., Kieser, T. \& Hopwood, D. A. (1992). A combined genetic and physical map of the chromosome of Streptomyces coelicolor A3(2). J Bacteriol 174, 5496-5507.

Kleinkauf, H. \& von Döhren, H. (1996). A non-ribosomal system of peptide biosynthesis. Eur J Biochem 236, 335-351.

Lakey, J. H. \& Ptak, M. (1988). Fluorescence indicates a calciumdependent interaction between the lipopeptide antibiotic LY146032 and phospholipid membranes. Biochemistry 27, 46394645 .

Lakey, J. H., Lea, E. J. A., Rudd, B. A. M., Wright, H. M. \& Hopwood, D. A. (1983). A new channel-forming antibiotic from Streptomyces coelicolor A3(2) which requires calcium for its activity. J Gen Microbiol 129, 3565-3573.

Lakey, J. H., Maget-Dana, R. \& Ptak, M. (1988). Conformational change on calcium binding by the lipopeptide antibiotic amphomycin. Biochem Biophys Res Commun 150, 384-390.

Lipmann, F. (1980). Bacterial production of antibiotic polypeptides by thiol-linked synthesis on protein templates. $A d v$ Microb Physiol 21, 227-266.

MacNeil, D. J., Gewain, K. M., Ruby, C. L., Dezeny, G., Gibbons, P. H. \& MacNeil, T. (1992). Analysis of the Streptomyces avermitilis genes required for avermectin biosynthesis utilizing a novel integration vector. Gene 111, 61-68.

Paget, M. S. B. (1994). Gene regulation and expression vector development in Streptomyces. PhD thesis, University of Manchester Institute of Science and Technology.

Podmore, S. M. (1995). Phenotypic and molecular genetic studies on the production of the calcium-dependent antibiotic of Streptomyces coelicolor A3(2). PhD thesis, University of Manchester Institute of Science and Technology.

Redenbach, M., Kieser, H. M., Denapaite, D., Eichner, A., Cullum, J., Kinashi, H. \& Hopwood, D. A. (1996). A set of ordered cosmids and a detailed genetic and physical map for the $8 \mathrm{Mb}$ Streptomyces coelicolor A3(2) chromosome. Mol Microbiol 20, 77-96.

Revill, W. P., Bibb, M. J. \& Hopwood, D. A. (1995). Purification of a malonyltransferase from Streptomyces coelicolor A3(2) and analysis of its genetic determinant. J Bacteriol 177, 3946-3952.

Revill, W. P., Bibb, M. J. \& Hopwood, D. A. (1996). Relationships between fatty acid and polyketide synthases from Streptomyces coelicolor A3(2). Characterization of the fatty acid synthase carrier protein. J Bacteriol 178, 5660-5667.

Sambrook, J., Fritsch, E. F. \& Maniatis, T. (1989). Molecular Cloning: a Laboratory Manual, 2nd edn. Cold Spring Harbor, NY: Cold Spring Harbor Laboratory.

Stachelhaus, T. \& Marahiel, M. A. (1995). Modular structure of genes encoding multifunctional peptide synthetases required for non-ribosomal peptide synthesis. FEMS Microbiol Lett 125, 3-14.

Stachelhaus, T., Schneider, A. \& Marahiel, M. A. (1995). Rational design of peptide antibiotics by targeted replacement of bacterial and fungal domains. Science 269, 69-72.

Stachelhaus, T., Schneider, A. \& Marahiel, M. A. (1996). Engineered biosynthesis of peptide antibiotics. Biochem Pharmacol 52, 177-186.

Stein, T. \& Vater, J. (1996). Amino-acid activation and polymerization at modular multienzymes in non-ribosomal peptide biosynthesis. Amino Acids 10, 201-227. 
Turgay, K. \& Marahiel, M. A. (1994). A general approach for identifying and cloning peptide synthetase genes. Pept Res 7, 238-241.

Turgay, K., Krause, M. \& Marahiel, M. A. (1992). Four homologous domains in the primary structure of GrsB are related to domains in a superfamily of adenylate-forming enzymes. Mol Microbiol 6, 529-546.

Wright, F. \& Bibb, M. J. (1992). Codon usage in the G+C-rich Streptomyces genome. Gene 113, 55-65.

Yu, T.-W. \& Hopwood, D. A. (1995). Ectopic expression of the
Streptomyces coelicolor whiE genes for polyketide spore pigment synthesis and their interaction with the act genes for actinorhodin biosynthesis. Microbiology 141, 2779-2791.

Zuber, P., Nakano, M. M. \& Marahiel, M. A. (1993). Peptide antibiotics. In Bacillus subtilis and Other Gram-Positive Bacteria, pp. 897-916. Edited by A. L. Sonenshein, J. A. Hoch \& R. Losick. Washington, DC: American Society for Microbiology.

Received 9 July 1997; revised 25 September 1997; accepted 6 October 1997. 